only about one tenth of the annual Treasury grant, for all purposes, to the universities-and it can do no more (it was not intended to do more) than catalyse the interest of the universities themselves and perhaps of their potential benefactors. That, however, it is beginning to do, and although the $£ 230,000$ itself cannot be spent otherwise than on facilities for healthy recreation-on gymnasia, swimming baths, squash courts and the like-it has set the universities thinking and planning, and ultimately very much more may result. In most of them-indeed if not all-voluntary medical examinations are to be instituted, lectures will doubtless be given on matters relating to health, the status of members of the staff dealing with physical training is to be raised, the co-operation of scientific and medical departments is to be sought, committees are to be formed to consider the place of student health as a proper function of a university ; and probably, under the guidance of the Medical Research Council, in certain special centres, a scientific examination of the problem is to be instituted. An attempt is to be made, in fact, to give to the subject of bodily and mental health and fitness its proper university status. Those, however, who take a longer view will realize that it is not merely 'student health' as such which is to be aimed at, but-through the universitiesthe intelligent and conscious application of a new biological outlook on human beings, an outlook intended ultimately to affect the entire community.

Health is a positive thing, namely, living up to the best powers of the individual. It is not merely absence of obvious diagnosable disease. As a matter of fact, however, even among students, disease is common enough. A professor in a medical school writes :

"Recently there have come within my notice four students with mild or severe mental trouble, three cases of early tuberculosis, and a host of minor ailments, such as trouble with hearing, vision and teeth, tonsils, colds, influenza, muscular pains, skin diseases, lassitude, anæmia, and not so very infrequently fears about health."

What is true of medical students is just as truethough not perhaps so easily realized-of others. To recognize disease, or minor ailments, or chronic under-nutrition, or mental trouble, or anything lowering the level of happiness, fitness and usefulness in university students, and to provide means of improvement, are important enough. Even more important, however, in the long run, is to send out steadily. into the community a stream of intelligent and keen young people who have learned, even in a minor way, what a health service can do for them and their friends, and how necessary it is to the happiness and well-being of the people.

Medicine at present consists too largely of the diagnosis and treatment of obvious disease, often when it is too late for complete health ever to be restored. Hospitals are crowded and only urgent cases can be considered. Human biology must take a much wider view than this of its duties and opportunities. Adequate nutrition, in quantity and quality, exercise suited to the needs and powers of the individual, healthy recreation, a sane outlook on bodily functions-not disregarding sex and reproduction-guidance and help in mental and emotional difficulty, the profitable use of holidays and leisure, all these require an educated public opinion. How better. may that educated opinion be built up than by giving to those who pass through the universities some personal appreciation and understanding of the part which an adequate health service, taking account of all such factors and employing all the resources of science, can play in promoting the well-being of those whom it reaches?

\title{
Protection of Ancient Monuments in Britain*
}

$\mathrm{T}$ HE recently issued list of monuments in England, Wales and Scotland now protected under the Ancient Monuments Acts contains the names of more than five thousand monuments. These are of all kinds from prehistoric camps, stone circles, and barrows to the remains of abbeys,

- Ancient Monuments of Great Britain : List of Monuments to Ancient Monuments of Great Britain : List of Monuments to
December 31, 1937, prepared by the Commissioners of Works. Pp. December 31, 1937, prepared by the Commissioners of Wor
101. (London: H.M. Stationery Office, 1938.) 18. 6 d. net. castles, bridges and even relatively modern buildings. Three hundred and twenty-five monuments were added to the list in 1937. Especially noteworthy among the additions are Bewcastle Roman fort, St. Alban's Gatehouse, with its archway and turrets, Reigate old town hall, which it had been proposed to demolish, the remains of the palace of Archbishop Roger at York, dating from the 
twelfth century, and the remains of the monastic settlement on Faroe Island.

Although the list is known not to be exhaustive, as is pointed out by Sir Patrick Duff in his introductory note, it serves to indicate the wealth of Great Britain in remains of historic and æsthetic interest, as well as the multifarious activities of the Ancient Monuments Branch of the Office of Works. Between 1921 and 1931 the Commissioners published lists which indicated from time to time the monuments to which State protection had been granted under the Act of 1913 ; but since 1931, when the new Act was passed, the list, which it is incumbent on the Commissioners to publish under the law, has been made more comprehensive by the inclusion of those monuments appearing in previous lists, as well as certain classes of monuments for which the Commissioners are responsible in various ways by deed of gift, guardianship, or purchase, or as Crown property, or as situated on Crown property, though not under custody. There also appear the buildings of historic or architectural interest, some wholly or partially in occupation, for the maintenance of which the Office of Works is responsible. Among those in this last category are the Banqueting Hall, Whitehall, the Jewel Tower, Westminster, Holyrood. house, Edinburgh, Glasgow Cathedral and Dunblane Cathedral.

The interest of the list to the general public, and even its value to the expert, might be considerably enhanced by some such additions as a brief statistical statement in the nature of a progress report, an indication of the latest inclusions, and the date of protection of each monument. Although the introductory note records recognition by the Commissioners of the assistance of local archæologists in compiling the lists, archæologists on their side would acknowledge that the organization and personnel of the Ancient Monuments branch of the Office of Works, as at present constituted, provide a combination of scientific knowledge and practical training and experience best calculated to secure the co-operation of Government department and public, represented by the local expert, which it is the aim of successful administration in a democratic community to secure.

The departmental inertia in matters affecting our antiquities, which caused General Pitt-Rivers to refuse for many years to draw his salary as inspector of ancient monuments, has long been a thing of the past; and Sir Frederic Kenyon in his presidential address to the Society of Antiquaries on April 28 was fully justified in referring to the work of the Commissioners through the ancient monuments inspectorate as the most striking advance in the official recognition of archæology in our time. When, however, Sir Patrick Duff says that "the present enlarged list cannot be regarded as covering in a systematic way the whole of the more important Ancient Monuments of Great Britain", and Sir Charles Peers can tell the Oxford Branch of the Council for the Preservation of Rural England, at the meeting at Oxford on April 30, that the work already done in the protection of ancient monuments is no more than a beginning, it is evident that no means should be neglected to enlist the interest of the public, if the State, as many would like to see, is to take a greater and more responsible share in the systematic advancement of archæological knowledge. The more widely it is known how much is already accomplished by the Office of Works in the course of the year, the more readily will it be possible to win public support for an extension of its activities.

\section{Ideals and Conflicts of Civilization}

\section{Ends and Means :}

an Enquiry into the Nature of Ideals and into the Methods employed for their Realization. By Aldous Huxley. Pp. v+336. (London: Chatto and Windus, 1938.) $8 s .6 d$. net.

SIX years ago Mr. Huxley presented to the $S$ world the picture of a "Brave New World". The days of that scientific Utopia, so cleverly constructed with satire and malice out of $\mathrm{Mr}$. Huxley's rich imagination, are gone. The brave new world is changed to the Utopia of an evangelist, a Utopia seen through the haze of an infinitely troubled world. "Ends and Means" deals with the critical state of present world conditions and with the ideal individual. It considers the problems of domestic and international politics, of education, of religion and ethics, and in it Mr. Huxley tries to suggest a way out of the conflicts which now threaten the destruction of civilization.

Mr. Huxley has applied himself to his task with a faith that cannot fail to command respect, and 